\title{
永久磁石材料の現状と将来 \\ Present State and Future of Permanent Magnet Materials
}

\author{
小林 久理眞 \\ Kurima Kobayashi \\ 静岡理工科大学
}

Shizuoka Institute of Science and Technology

近年の電気自動車，ハイブリッドカーなど自動車関連部品 やエアコンなどの家電製品への応用拡大により, 永久磁石の 用途，使用量は増加の一途をたどっている．これまではネオ ジム磁石を主役として, 材料研究, 生産技術開発が進んでき たが, 最近, $\mathrm{Sm}_{2} \mathrm{Fe}_{17} \mathrm{~N}_{3}$ 系粉体磁石の高密度化, Sm-Co 系磁 石の高性能化, $\mathrm{Mn}-\mathrm{Bi}$ 系磁石や $\mathrm{ThMn}_{12}$ 型構造を有する新規 磁石など，いくつかの新展開が見られる。 そこで, 本講演特 集では, それらの話題についてセッションを組み, 講演と議 論をいただいた。

最初のセッションでは, Sr-La-Co 系フェライト磁石磁気異 方性と角形比について招待講演をいただき, 続けて Nd-Fe-B 系焼結磁石の粒界改質につき発表があった，さらに，同磁石 粉体の熱間加工バルク磁石と射出成型ボンド磁石について報 告された.

第 2 セッションでは, $\mathrm{ThMn}_{12}$ 型構造磁石と類似組成の急 冷薄帯について, 計算物理的な検討 (特別講演), 実際の薄 膜合成 (招待講演), 微細組織と磁気特性相関性の検討, さ らに，物性測定のための飽和漸近則応用の精密な解析などの
講演があった。

第 3 セッションでは, 協会賞受賞記念講演として Sm-Co 系磁石の高性能化と, そのためのプロセス検討の詳細な解説 をいただき，続けて，招待講演として放電プラズマ焼結法に よる $\mathrm{Sm}-\mathrm{Co}$ 磁石と, $\mathrm{Mn}-\mathrm{Bi}$ 系磁石調製法の検討について講 演いただいた，Mn-Bi 系磁石については，さらに，製法上の 重要点について電気化学的検討を行った報告もあった.

第 4 セッションは, 特別講演の Sm-Fe-N 系焼結磁石の開発 の報告をはじめ, $\mathrm{Sm}_{2} \mathrm{Fe}_{17} \mathrm{~N}_{3}$ 系および $\mathrm{Tb}_{1} \mathrm{Cu}_{7}$ 型構造の同種粉 体について, 粉体コーティング, HDDR 処理, さらに新規な 磁区構造観察法について報告があった。このセッションの最 後に Nd-Fe-B 系磁石の HD 処理後に冷間成形を行う試みにつ いて講演があった。

講演募集中は, 最近永久磁石関連の学会, シンポジウムも 多いため，講演が集まるかどうか懸念されたが，結果は多く の講演をいただき, 質問も活発で, よい講演特集になった. 講演者と会場参集いただきました皆様に深く感謝致します。 